\title{
ORIENTASI KEWIRAUSAHAAN, INOVASI PRODUK, DAN MEDIA SOSIAL TERHADAP KINERJA PEMASARAN DENGAN KEUNGGULAN BERSAING SEBAGAI INTERVENING PADA UKM DI KOTA JAMBI
}

\author{
Yosi Fadhillah*1, Syahmardi Yacob ${ }^{2}$, Tona Aurora Lubis ${ }^{3}$ \\ ${ }^{123}$ Manajemen, FEB, Universitas Jambi \\ e-mail: yosifadillah230@gmail.com
}

\begin{abstract}
Abstrak
Tujuan penelitian ini adalah untuk mengetahui pengaruh orientasi kewirausahaan, inovasi produk, dan media sosial terhadap kinerja pemasaran melalui keunggulan bersaing pada UKM di Kota Jambi. Pengumpulan data dilakukan dengan survei menggunakan kuesioner yang diberikan kepada 100 UKM di Kota Jambi. Alat analisis yang digunakan adalah Smart PLS 3. Hasil penelitian menunjukkan bahwa pengaruh langsung, Orientasi Kewirausahaan tidak berpengaruh terhadap keunggulan bersaing, inovasi produk berpengaruh terhadap keunggulan bersaing, media sosial berpengaruh terhadap keunggulan bersaing, orientasi kewirausahaan berpengaruh terhadap kinerja pemasaran, keunggulan bersaing berpengaruh terhadap kinerja pemasaran, Media Sosial berpengaruh terhadap Kinerja Pemasaran pada UKM di Kota Jambi dan kesimpulan dari pengaruh mediasi penelitian ini adalah keunggulan bersaing memiliki pengaruh mediasi terhadap variabel inovasi produk dan media sosial, sedangkan untuk variabel orientasi kewirausahaan tidak terdapat pengaruh mediasi.
\end{abstract}

Kata kunci : Orientasi Kewirausahaan; Inovasi Produk; Media Sosial; Keunggulan Kompetitif; dan Kinerja Pemasaran

\begin{abstract}
The purpose of this study was to determine the effect of entrepreneurial orientation, product innovation, and social media on marketing performance through competitive advantage in SMEs in Jambi City. Data collection was carried out by survey using a questionnaire given to 100 SMEs in Jambi City. The analytical tool used is Smart PLS 3.The results show that direct influence, entrepreneurial orientation has no effect on competitive advantage, product innovation affects competitive advantage, social media affects competitive advantage, entrepreneurial orientation affects marketing performance, competitive advantage affects performance Marketing, Social Media has an effect on Marketing Performance in SMEs in Jambi City and the conclusion of the mediation effect of this study is that competitive advantage has a mediating effect on product innovation and social media variables, while for entrepreneurial orientation variables there is no mediation effect
\end{abstract}

Keywords : Entrepreneurship Orientation; Product Innovation; Social Media; Competitive Advantage; and Marketing Performanc

\section{PENDAHULUAN}

Usaha Mikro, Kecil dan Menengah (UKM) mempunyai peran penting dan strategis dalam pembangunan ekonomi nasional UKM memiliki proporsi sebesar 99,99\% dari total keseluruhan pelaku usaha di Indonesia atau sebanyak 56,54 juta unit. Selain berperan dalam pertumbuhan ekonomi dan penyerapan tenaga kerja, UMKM juga berperan dalam 
mendistribusikan hasil-hasil pembangunan. UMKM juga telah terbukti tidak terpengaruh terhadap krisis. Ketika krisis menerpa pada periode tahun 1997 - 1998, hanya UMKM yang mampu tetap berdiri kokoh (Sarwono, 2015).

Dalam perkembangannya terdapat Usaha kecil yang mampu tumbuh dan berkembang menjadi usaha menengah dan usaha besar. Di setiap daerah ada potensi bagi usaha kecil untuk tumbuh berkembang, misalnya kebijakan pemerintah yang memberikan iklim yang kondusif bagi usaha kecil untuk berkembang, potensi sumber daya ekonomi daerah, keterkaitan usaha, dan berbagai program kemitraan usaha antara korporasi pemerintah dan swasta, misalnya corporate social responsibility program (Karim \& Hamdan, 2014).

Perkembangan UKM jumlah usaha Kecil Menegah Tahun 2013 adalah sebesar 2.050 unit, Jumlah Usaha kecil menegah tahun 2014 adalah sebesar 2.050 unit, jumlah usaha kecil menengah pada tahun 2015 adalah sebesar 4.470 unit, jumlah usaha kecil menengah pada tahun 2016 adalah sebesar 4.144 unit, jumlah usaha kecil menengah pada tahun 2017 adalah sebesar 4.144 unit, jumlah usaha kecil menengah pada tahun 2018 adalah sebesar 3.506 unit, dan jumlah usaha kecil menengah pada tahun 2019 adalah sebesar 3.506 unit.Bermunculannya usaha baru secara berkelanjutan membuat persaingan semakin ketat. Perubahan-perubahan yang terjadi dalam persaingan usaha menciptakan perubahan kebutuhan pelanggan, pengelolaan produk serta pangsa pasar. Karena jenis usaha mikro, kecil dan menengah seperti ini kebanyakan bersifat perorangan (Tawas \& Djodjobo, 2014).

Suryana \& Bayu (2010) Seorang wirausaha harus berani tampil beda, memiliki kualitas prima dan telah mempersiapkan para pemain, sekarang kunci peran ada pada diri sendiri, sebelum beranjak untuk berjalan maju, maka kunci peran harus dimantapkan terlebih dahulu, seperti orientasi kewirausahaan dimana penelitian Rosli Mahmood et al., (2013) mengungkapkan bahwa adanya hubungan signifikan antara orientasi kewirausahaan dan kinerja Hasilpenelitian ini bisa membantu UKM untuk lebih berorientasi kewirausahaan dan dikembangkannya keunggulan kompetitif dalam rangka bagi mereka untuk bertahan hidup lingkungan pasar yang sangat kompetitif akan tetapi Wardi et al., (2017) Berdasarkan hasil penelitiannya disimpulkan bahwa kinerja UKM dipengaruhi oleh orientasi kewirausahaan meliputi keinovasian, keproaktifan dan keberanian berisiko.

Selain orientasi kewirausahaan, inovasi produk tidak kalah penting. Produk yang ditampilkan oleh pemilik usaha harus memiliki inovasi (Tawas \& Djodjobo, 2014). Wirausahawan yang sukses memiliki ide dan kemudian mencari cara agar ide tersebut sukses memecahkan masalah atau memuaskan kebutuhan. Dalam dunia yang berubah lebih cepat daripada yang dapat kita bayangkan, kreativitas dan inovasi sangat penting bagi kesuksesan dan keberlangsungan perusahaan (Zimmerer et al., 2008).

Produk-produk UMKM yang dihasilkan memiliki potensi besar untuk berhasil di pasar nasional dan internasional, namun kelemahan UMKM selain akses perbankan dan pemasaran adalah pada aspek kewirausahaan dan manajemen. Keberanian mengambil resiko dalam berbisnis masih rendah, kemampuan untuk mengembangkan produk (inovasi) masih rendah dan kreativitas untuk menemukan ide-ide bisnis yang baru masih rendah. Pada aspek manajemen usaha meskipun telah mendapatkan pelatihan untuk menyusun / membuat laporan keuangan namun sebagian besar umkm belum menguasai dan menerapkan dalam berbisnis, ditambah lagi dengan rendahnya motivasi (Octavia et al., 2017)

Inovasi sangat penting ini didukung oleh penelitian Jayaningrum (2018), dimana Inovasi berpengaruh signifikan terhadap Keunggulan Bersaing. Semakin tinggi Inovasi maka Keunggulan Bersaing pun semakin tinggi. Inovasi dapat dijadikan sebagai salah satu 
sumber keunggulan bersaing melalui kemampuan perusahaan perusahaan untuk beradaptasi dalam lingkungan yang dinamis. inovasi produk memiliki dampak langsung dan signifikan pada kinerja dan sangat memediasi hubungan antara wirausaha prokeaktifan dan kinerja (Angkanurakbun \& Wanarat, 2016).

Selain orentasi wirausaha dan inovasi produk, media sosial juga sangat penting dalam memasarkan produk. Nasrullah (2015), menyatakkan bahwa Media Sosial merupakan medium di internet yang memungkinkan penggunanya mempresentasikan dirinya maupun berinterakasi, bekerjasama, saling berbagi, berkomunikasi dengan pengguna lainnya, dan membentuk ikatan sosial secara virtual.

Persentase pengguna Media sosial yang paling aktif yang menggunakan setiap platform (berbasis survey) adalah sebagai berikut: Youtube: 88\%, Whatsapp: 83\%, Facebook: $81 \%$, dan Instagram: $80 \%$. Hasil dari analisis data menunjukkan hubungan positif dan signifikan antara penggunaan media sosial dan kinerja perusahaan (Tajvidi \& Karami, 2017). Mengacu pada data pengguna media sosial di Indonesia, menunjukkan bahwa penggunaan s-commerce sangat potensial dalam mendukung proses perdagangan maupun proses penciptaan. Namun hal ini menjelaskan bahwa penggunaan media sosial menjadi kegiatan komersial (s-commerce) di UKM masih rendah. Hal ini tentunya menjadi perhatian khusus, mengingat masih rendahnya persepsi sebagian besar pemilik UKM di Kota Jambi terhadap pemanfaatan s-commerce untuk kemajuan usahanya (Yacob et al., 2018)

Zimmerer et al., (2008) Sekumpulan factor yang membedakan perusahaann kecil dari para pesaingnya dan memberikannya posisi unik dipasar sehingga lebih unggul dari para pesaingnya. Dari perspektif strategis, kunci bagi kesuksesan bisnis adalah pengembangan keunggulan kompetitif yang unik, yaitu keunggulan yang menciptakan nilai bagi pelanggan dan sukar ditiru oleh para pesaing. Perusahaan yang memiliki keunggulan kompetitif akan menjadi pemimpin dalam pasarnya serta dapat mencapai laba di atas rata-rata.

Serta adanya research gap yang ditemukan yaitu penelitian yang dilakukan oleh Setyawati \& Abrilia (2013) Menemukan Hubungan antara Keunggulan Bersaing terhadap Kinerja adalah tidak signifikan sedangkan Brahmanthara \& Yasa (2017) Sebaliknya Keunggulan bersaing berpengaruh positif dan signifikan terhadap kinerja pemasaran, artinya apabila keunggulan bersaing mengalami perubahan maka kinerja pemasaran juga akan mengalami perubahan. Keunggulan bersaing berpengaruh secara positif dan signifikan terhadap kinerja pemasaran, dalam penelitian ini semakin baik keunggulan bersaing yang dimiliki UKM laundry maka akan semakin baik kinerja pemasaran yang didapat UKM laundry (Dewi \& Ekawati, 2017).

Kinerja Pemasaran Kinerja merupakan indikator-indikator keberhasilan kerja atau prestasi kerja sesungguhnya yang dicapai seseorang atau organisasi karena melaksanakan tugasnya dengan baik. Kinerja pemasaran selalu dipandang sebagai hasil dari dijalankannya sebuah peran stratejik tertentu. Bagi seorang tenaga penjualan kinerja dihasilkan sebagai akibat dari keagresifan tenaga penjualan mendekati dan melayani dengan baik pelanggannya (Augusty \& Asatuan, 2004) Dengan demikian penulis akan meneliti "Orientasi Kewirausahaan, Inovasi produk, dan Media Sosial terhadap kinerja pemasaran dengan keunggulan bersaing sebagai intervening Pada UKM di Kota Jambi" 


\section{KAJIAN PUSTAKA}

\section{Orientasi Kewirausahaan}

Orientasi kewirausahaan adalah pencarian peluang, keberanian mengambil resiko serta keputusan bertindak para pemimpin organisasi (Knight, 2016). Orientasi kewirausahaan merupakan sistem nilai perusahaan yang nantinya menentukan arah gerak atau strategi perusahaan. Dess (2005), Orientasi kewirausahaan merupakan pembuatan strategi praktik yang digunakan bisnis untuk mengidentifikasi dan meluncurkan usaha perusahaan. Orientasi kewirausahaan terbagi dalam lima dimensi (Lumpkin \& Dess, 1996)

\section{Keinovatifan (innovativeness)}

Keinovatifan adalah kencenderungan untuk terlibat dalam kreativitas dan eksperimen melalui pengenalan produk atau jasa baru serta kepemimpinan teknologi melalui riset dan pengembangan dalam proses-proses baru.

2. Pengambilan resiko (risk tasking)

Pengambilan resiko adalah pengambilan tindakan tegas dengan mengeksplorasi hal yang tidak diketahui, meminjam dalam jumlah besar, dan / atau mengalokasi sumber daya yang signifikan untuk usaha di lingkungan yang tidak pasti.

3. Keaktifan (proactiveness)

Keaktifan adalah sebuah pencarian peluang, perspektif memandang ke depan yang ditandai dengan pengenalan produk baru atau jasa baru lebih dulu dalam persaingan dan bertindak dalam mengantisipasi permintaan masa mendatang.

4. Keagresifan bersaing (competitive aggressiveness)

Keagresifan bersaing adalah intensitas dari upaya-upaya perusahaan untuk mengungguli pesaing dan ditandai oleh sikap atau tanggapan ofensif atau respon agresif terhadap tindakan-tindakan pesaing.

5. Otonomi (autonomy)

Otonomi meruipakan untuk bekerja secara mandiri, membuat keputusan dan mengambil tindakan yang bertujuan untuk memajukan konsep bisnis dan membayanya pada penyelesaian.

\section{Inovasi Produk}

Inovasi adalah perubahan dan peningkatan teknologi, produk, proses, dan layanan yang memberikan kontribusi positif bagi pelanggan dan konstituen lainnya organisasi bisnis. Inovasi adalah solusi baru yang kreatif untuk yang berlaku kondisi dan tren, dan memenuhi kebutuhan dan keinginan pelanggan yang diekspresikan dan laten dan pemangku kepentingan (Rainey, 2005).

Sedangkan Menurut Machfoedz \& Machfoedz (2004) bahwa inovasi produk terdiri dari 4 indikator, yaitu :

\section{Penemuan}

Dikatakan penemuan adalah kreasi suatu produk, jasa, atau proses baru yang belum pernah dilakukan sebelumnya, konsep ini cenderung disebut revolusioner.

2. Pengembangan

pengebembangan adalah kelanjutan perubahan, perbaikan dari suatu produk, jasa, maupun proses yang sudah ada sebelumnya dan konsep seperti ini menjadikan aplikasi ide yang telah ada dan berbeda. 
3. Duplikasi

Duplikasi ini adalah peniruan suatu produk, jasa, maupun proses yang telah ada, namun demikian upaya duplikasi bukan semata - mata meniru, melainkan menambah sentuhan kreatif untuk memperbaiki konsep agar lebih mampu memenangi persaingan.

4. Sinetesis

Sinetesis adalah perpaduan konsep dan faktor yang telah ada menjadi formula baru. Proses ini meliputi pengambilan sejumlah ide atau produk yang telah ditemukan dan dibentuk sehingga menjadi produk yang dapat diaplikasikan dengan cara baru.

\section{Media Sosial}

Keller (2016), Media sosial adalah sarana bagi konsumen untuk berbagi teks, gambar, audio, dan informasi video satu sama lain dan dengan perusahaan, dan sebaliknya. Media sosial memungkinkan pemasar untuk membentuk suara publik dan kehadiran online. Mereka dapat memperkuat secara hemat biaya kegiatan komunikasi lainnya (Keller, 2016).

Media sosial merupakan berbagai platform yang tersedia di Internet, yang memberi pengguna kesempatan untuk membuat profil mereka dan berbagi dan mempromosikan konten. Platform media sosial ini semuanya dirancang untuk membantu orang dan perusahaan membangun kehadiran sosial dan memberi tahu orang lain tentangnya produk dan layanan mereka (Kennedy, 2015).

Popularitas media sosial, sebagai alat pemasaran, meningkat dalam dekade terakhir karena semakin banyak perusahaan menyadari potensi sebenarnya dan mulai menggunakannya keuntungan mereka. Mereka mengerti bahwa mereka bisa menjangkau lipatan (Kennedy, 2015).

\section{Keunggulan Bersaing}

Keunggulan bersaing adalah ketika tindakan-tindakan dalam suatu industri atau pasar menciptakan nilai ekonomi dan ketika beberapa perusahaan yang bersaing terlibat dalam tindakan serupa (Barney \& Clark, 2010). Keunggulan kompetitif adalah perusahaan yang memiliki daya saing keuntungan ketika mampu menciptakan nilai ekonomi lebih dari perusahaan saingan (Barney \& Hesterly, 2015).

Menurut Porter (1990), strategi memugkinkan organisasi untuk memperoleh keunggulan kompetitif dari tiga landasan yang berbeda :

1. Keunggulan/kepemimpinan biaya (cost leadership)

Adalah menekankan pemroduksian produk - produk yang distandardisasi dengan biaya perunit yang sangat rendah untuk para konsumen yang peka terhdap harga.

2. DiferensiasiPembedaan / diferensiasi (Differentiation) adalah sebuah strategi yang bertujuan menghasilkan produk atau jasa yang dianggap unik di industri dan diarahkan kepada konsumen yang relative peka terhadap harga.

3. Fokus (Focus)

Fokus (Focus) berarti memproduksi produk dan jasa yang memenuhi kebutuhan sekelompok kecil konsumen.

\section{Kinerja Pemasaran}

Kinerja pemasaran adalah konstruk (factor) yang digunakan untuk mengukur dampak dari sebuah strategi perusahan. Strategi perusahaan selalu diarahkan untuk menghasilkan kinerja baik berupa kinerja pemasaran maupun kinerja keuangan (Ferdinand, 2000). kinerja pemasaran adalah akumulasi hasil akhir dari seluruh aktivitas 
dan proses kerja dari perusahaan atau suatu tampilan keadaan secara utuh atas perusahaan selama periode waktu tertentu, yang merupakan hasil atau prestasi yang dipengaruhi oleh kegiatan operasional perusahaan dalam memanfaatkan sumber-sumber daya yang dimiliki (Sampurno, 2010).

Ferdinand (2000) Kinerja pemasaran yang baik dinyatakan dalam tiga besaran utama yaitu

1.Nilai penjualan yang ditunjukkan dengan nilai keuntungan uang atau unit produk yang terjual

2.Pertumbuhan penjualan yang ditunjukan dengan kenaikan penjualan produk yang sama dibandingkan satuan waktu tertentu.

3.Porsi pasar yang ditunjukkan dengan kontribusi produk dalam menguasai pasar produk dibanding dengan kompetitor yang pada akhirnya bermuara pada keuntungan perusahaan.

\section{METODE PENELITIAN}

\section{Rancangan Penelitian}

Rancangan penelitian yang digunakan dalam penelitian ini adalah deskriptif , statistik dan survey, tujuan deskriptif adalah untuk mendeskripsikan Orientasi Kewirausahaan, Inovasi produk, dan Media Sosial terhadap kinerja pemasaran dengan keunggulan bersaing sebagai intervening Pada UKM di Kota Jambi. Sedangkan tujuan statistik adalah untuk menjelaskan hubungan sebab akibat antara variabel yang dilibatkan dalam penelitian. Dalam penelitian ini peneliti melakukan penyebaran kuesioner secara online melalui googleforms.

\section{Sampel}

Populasi dalam penelitian ini adalah pelaku usaha kecil dan menengah yang berada di kota Jambi. Jumlah sampel 100 UKM. Teknik pangambilan sampel menggunakan purposive sampling, yaitu Teknik penentuan sampel dengan pertimbangan tertentu (Sugiyono, 2017). Kriteria sampel yang dipilih dalam penelitian ini adalah : Wanita dan Pria yang berusia 15 - > 55 tahun, Telah menjalankan usaha minimal selama 1 Tahun dan UKM kota jambi

\section{Analisis Data}

Teknik analisis data yang digunakan adalah teknik analisis data kuantitatif, yaitu analisis yang digunakan untuk menguji hubungan atau pengaruh Orientasi Kewirausahaan, Inovasi produk, dan Media Sosial terhadap kinerja pemasaran dengan keunggulan bersaing sebagai intervening Pada UKM di Kota Jambi. Instrumen yang digunakan dalam penelitian ini adalah angket dengan format skala likert. Skala likert digunakan untuk mengukur sikap, pendapat, dan persepsi seseorang atau sekelompok terhadap fenomena sosial yang diskalakan dengan 5 poin. Alternatif jawaban diawali dengan skor 1 yang berarti sangat tidak setuju s / d skor 5 yang berarti sangat setuju dan Analisis Statistik Inferensia Statistik Inferensial Menurut Sugiyono (2017), statistik inferensial adalah statisik yang digunakan untuk menarik inferensi dari sampel ke populasi. Statistik inferensial adalah statistik yang digunakan untuk menarik inferensi dari sampel ke populasi (Sugiyono, 2017)

Data diolah dengan menggunakan Partial Least Square (PLS), yang merupakan "metode analisis yang ampuh karena dapat diterapkan pada semua skala data, tidak memerlukan banyak asumsi dan ukuran sampel tidak boleh besar. (Wiyono, 2011)PLS 
merupakan metode analisis yang powerfull karena dapat diterapkan pada semua skala data, tidak banyak membutuhkan asumsi, dan ukuran sampel tidak harus besar. Selain dapat digunakan untuk konfirmasi teori, PLS juga dapat digunakan untuk membangun hububungan yang belum ada landasan teorinya atau untuk pengujian proposisi. Analisis mediasi dengan Sobel Test,Uji Sobel ini digunakan untuk mengetahui pengaruh variabel mediasi yaitu Kinerja Karyawan. Suatu variabel disebut intervening jika variabel tersebut ikut mempengaruhi hubungan antara variabel independen dan variabel dependen (Baron dan Kenny (1986) dalam Ghazali (2011) Uji Sobel untuk menguji kekuatan dari pengaruh tidak langsung variabel independen (X) ke variabel dependen (Y) melalui vanriabel ntervening $(\mathrm{Z})$.

\section{HASIL DAN PEMBAHASAN}

Tabel results for inner weights dari hasil running bootstrapping digunakan untuk mengetahui pengaruh langsung antar variabel dari masing-masing hipotesis. Caranya adalah melihat nilai koefesien jalur dari masing-masing hipotesis dan nilai t-stat. Nilai koefesien yang baik harus melebihi $>0.5$ Koefisien ini bersumber dari kolom original sample estimate. Nilai t-stat bersumber dari kolom $t$-stat pada tabel results for inner weights. Nilai t-stat yang berada diatas nilai 1,96 menunjjukan pengaruh langsung signifikan dari masing-masing hipotesis

Tabel 1

Pengujian Hipotesis

\begin{tabular}{|l|r|r|r|r|r|}
\hline & \multicolumn{1}{|l|}{$\begin{array}{l}\text { Original } \\
\text { Sample } \\
\text { (O) }\end{array}$} & $\begin{array}{l}\text { Sample } \\
\text { Mean (M) }\end{array}$ & $\begin{array}{l}\text { Standard } \\
\text { Deviation } \\
\text { (STDEV) }\end{array}$ & $\begin{array}{l}\text { T Statistics } \\
\text { (|O/STDEV|) }\end{array}$ & P Values \\
\hline $\begin{array}{l}\text { X1 (Orientasi } \\
\text { Kewirausahaan) -> Y } \\
\text { (Kinerja Pemasaran) }\end{array}$ & 0.480 & 0.487 & 0.073 & 6.542 & 0.000 \\
\hline $\begin{array}{l}\text { X1 (Orientasi } \\
\text { Kewirausahaan) -> Z }\end{array}$ & 0.025 & 0.029 & 0.120 & 0.207 & $\mathbf{0 . 8 3 6}$ \\
\hline X2 (Inovasi Produk) -> Z & 0.416 & 0.411 & 0.104 & 4.007 & 0.000 \\
\hline $\begin{array}{l}\text { X3 (Media Sosial) -> Y } \\
\text { (Kinerja Pemasaran) }\end{array}$ & 0.247 & 0.245 & 0.083 & 2.967 & 0.003 \\
\hline X3 (Media Sosial) -> Z & 0.496 & 0.495 & 0.103 & 4.834 & 0.000 \\
\hline Z -> Y (Kinerja Pemasaran) & 0.260 & 0.254 & 0.078 & 3.320 & 0.001 \\
\hline
\end{tabular}

Berdasarkan tabel 1, hasil pengujian hipotesis dengan t-statistics dapat dijelaskan sebagai berikut:

Pengaruh Langsung

1. Pengaruh Orientasi Kewirausahaan terhadap Keunggulan bersaing

Nilai t-statistic Orientasi Kewirausahaan terhadap Keunggulan bersaing 0,207 lebih kecil dari t-tabel 1,96. Hasil ini menjelaskan bahwa Orientasi Kewirausahaan tidak berpengaruh signifikan terhadap Keunggulan bersaing.

2. Inovasi Produk terhadap Keunggulan bersaing

Nilai t-statistic Inovasi Produk terhadap Keunggulan bersaing 4,007 lebih besar dari ttabel 1,96. Hasil ini menjelaskan bahwa Inovasi produk berpengaruh signifikan terhadap Keunggulan bersaing.

3. Media Sosial terhadap Keunggulan bersaing 
Nilai t-statistic Media Sosial terhadap Keunggulan bersaing 4,834 lebih besar dari ttabel 1,96. Hasil ini menjelaskan bahwa Media Sosial berpengaruh signifikan terhadap Keunggulan bersaing.

4. Pengaruh Orientasi Kewirausahaan terhadap Kinerja pemasaran

Nilai t-statistic Orientasi Kewirausahaan terhadap Kinerja pemasaran 6,542 lebih besar dari t-tabel 1,96. Hasil ini menjelaskan bahwa Orientasi Kewirausahaan berpengaruh signifikan terhadap Kinerja pemasaran.

5. Keunggulan bersaing terhadap Kinerja pemasaran

Nilai t-statistic Keunggulan bersaing terhadap Kinerja pemasaran 3,320 lebih besar dari t-tabel 1,96. Hasil ini menjelaskan bahwa Keunggulan bersaing berpengaruh signifikan terhadap Kinerja pemasaran.

6. Media Sosial terhadap Kinerja Pemasaran

Nilai t-statistic Media Sosial terhadap Kinerja Pemasaran 2,967 lebih besar dari ttabel 1,96. Hasil ini menjelaskan bahwa Media Sosial berpengaruh signifikan terhadap Kinerja Pemasaran.

\section{Pengaruh Tidak Langsung}

7. Orientasi Kewirausahaan dimediasi keunggulan bersaing terhadap kinerja pemasaran

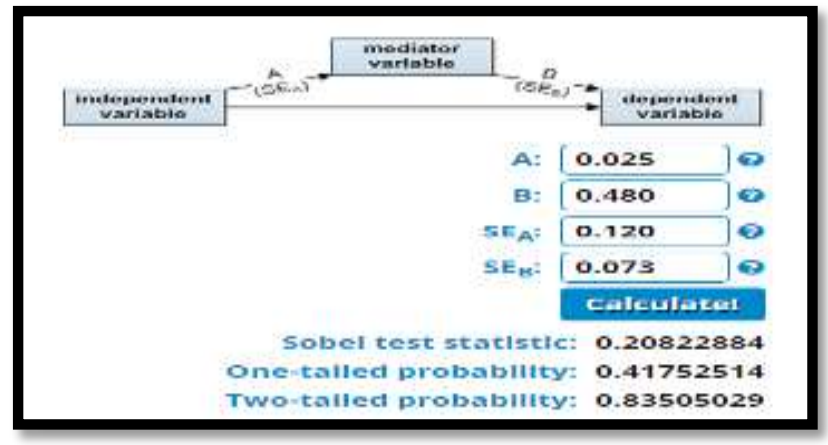

Gambar 1. Uji Sobel Hipotesis 7

Dan hasil perhitungan sobel test diperoleh nilai -statistic sebesar 0, 208 karena nilai $\mathrm{t}$ statistic yang diperoleh sebesar 0,208 < 1,985 dengan tingkat signifikansi 0,835 $>0,10$ maka membuktikan bahwa keunggulan bersaing (Z) tidak mampu memediasi hubungan pengaruh Orientasi Kewirausahaan terhadap Kinerja Pemasaran hipotesis 7 ditolak.

8. Inovasi produk dimediasi keunggulan bersaing terhadap kinerja pemasaran

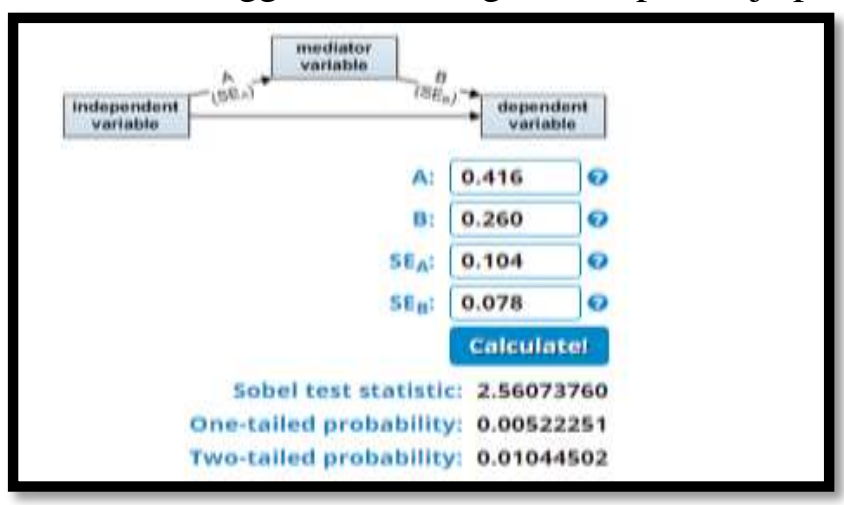

Gambar 2. Uji Sobel Hipotesis 8 
Dan hasil perhitungan sobel test diperoleh nilai -statistic sebesar 2,560 karena nilai t statistic yang diperoleh sebesar 2,560 > 1,985 dengan tingkat signifikansi $0,010<0,10$ maka membuktikan bahwa keunggulan bersaing (Z) mampu memediasi hubungan pengaruh inovasi produk terhadap Kinerja Pemasaran hipotesis 8 diterima.

9. Media Sosial dimediasi keunggulan bersaing terhadap kinerja pemasaran

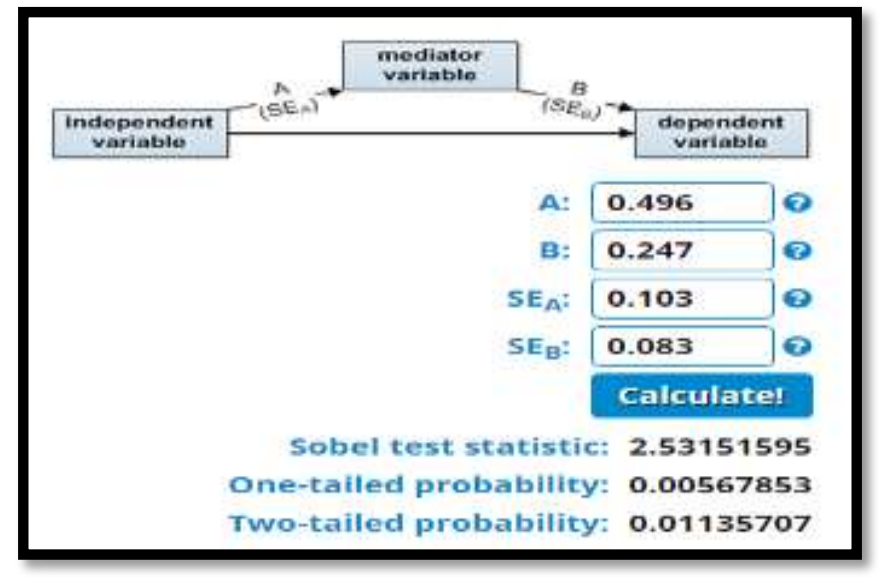

Gambar 3. Uji Sobel Hipotesis 9

Dan hasil perhitungan sobel test diperoleh nilai -statistic sebesar 2,531 karena nilai $\mathrm{t}$ statistic yang diperoleh sebesar 2,531 > 1,985 dengan tingkat signifikansi $0,011<0,10$ maka membuktikan bahwa keunggulan bersaing (Z) mampu memediasi hubungan pengaruh media sosial terhadap Kinerja Pemasaran hipotesis 9 diterima.

\section{Pembahasan}

\section{Orientasi Kewirausahaan Berpengaruh Signifikan Terhadap Keunggulan Bersaing}

Demikian dapat disimpulkan bahwa Orientasi Kewirausahaan yang direfleksikan oleh Keinovatifan (X1.1), Pengambilan Resiko (X1.2), Keaktifan (X1.3), Keagresifan Bersaing (X1.4) dan Otonomi (X1.5) tidak mempunyai pengaruh yang Signifikan terhadap Keunggulan bersaing $(Z)$ yang direfleksikan oleh yaitu Diferensiasi (Z1.2), dan Fokus (Z1.3). Dengan memperhatikan nilai original sample estimete yang positif dan tidak signifikan tersebut maka dapat disimpulkan bahwa Orientasi Kewirausahaan tidak akan meningkatkan Keunggulan bersaing baik dari diferensiasi dan fokus

Penelitian ini tidak sejalan dengan Penelitian yang dilakukan Yaseen Zeebaree \& Siron (2017), Hasil penelitian ini menunjukkan bahwa orientasi kewirausahaan berpengaruh signifikan terhadap keunggulan bersaing (CMA). Hasilnya juga menyoroti bahwa FNC memilikinya peran moderat dalam hubungan antara orientasi kewirausahaan dan CMA di UKM di KRG Irak. Pada perbedaan ini, ada beberapa sebab di antarannya adalah adanya sampelnya besar yaitu 680 UKM, sedangkan penelitian ini hanya menggunakan 100 sampel.

\section{Inovasi Produk Berpengaruh Signifikan Terhadap Keunggulan Bersaing}

Demikian dapat disimpulkan bahwa Inovasi produk (X2) direfleksikan oleh Penemuan (X2.1), Pengembangan (X2.2), Duplikasi (X2.3) dan Sinetesis (X2.4). mempunyai pengaruh yang Signifikan terhadap Keunggulan bersaing $(Z)$ yang direfleksikan oleh yaitu Diferensiasi (Z1.2), dan Fokus (Z1.3). Dengan memperhatikan nilai original sample estimete yang positif dan signifikan tersebut maka dapat disimpulkan bahwa Inovasi Produk akan meningkatkan Keunggulan bersaing baik dari diferensiasi dan fokus 
Hal tersebut sejalan dengan penelitian, Pada penelitian yang dilakukan Siqueira \& Cosh (2008), Hasil penelitian menunjukkan bahwa perusahaan yang menggunakan rotasi pekerjaan atau multiskilling dan memperkenalkan inovasi produk secara konsisten dari tahun 2002 hingga 2004 lebih banyak kemungkinan besar akan berkinerja terbaik di tahun 2004. Temuan ini mendukung model teoretis yang sesuai di mana hubungan antara kapabilitas dan keunggulan kompetitif dimoderasi oleh inovasi.

\section{Media Sosial Berpengaruh Signifikan Terhadap Keunggulan Bersaing}

Demikian dapat disimpulkan bahwa Media Sosial direfleksikan oleh indikator Partisipasi (X3.1), Keterbukaan (X3.2), Percakapan (X3.3), Komunitas (X3.4) dan Keterhubungan (X3.5). mempunyai pengaruh yang Signifikan terhadap Keunggulan bersaing (Z) yang direfleksikan oleh indikator Diferensiasi (Z1.2), dan Fokus (Z1.3). Dengan memperhatikan nilai original sample estimete yang positif dan signifikan tersebut maka dapat disimpulkan bahwa media sosial akan meningkatkan Keunggulan bersaing baik dari diferensiasi dan fokus

Hal tersebut sejalan dengan penelitian Pranaka et al., (2017) Hasil penelitian menunjukkan Media sosial mempengaruhi secara signifikan sebesar $74 \%$ terhadap keunggulan bersaing pada Guten Inc. Iklan melalui media sosial mempengaruhi secara signifikan sebesar 59,9\% terhadap keunggulan bersaing pada Guten Inc. Promosi melalui media sosial mempengaruhi secara signifikan sebesar 36\% terhadap keunggulan bersaing pada Guten Inc. Brand Awareness melalui media sosial mempengaruhi secara signifikan sebesar $73 \%$ terhadap keunggulan bersaing pada Guten Inc.

\section{Orientasi Kewirausahaan Berpengaruh Signifikan Terhadap Kinerja Pemasaran}

Demikian dapat disimpulkan bahwa Orientasi Kewirausahaan direfleksikan oleh indikator Keinovatifan (X1.1), Pengambilan Resiko (X1.2), Keaktifan (X1.3), Keagresifan Bersaing (X1.4) dan Otonomi (X1.5) mempunyai pengaruh yang Signifikan terhadap kinerja pemasaran yang direfleksikan oleh indikator Nilai Penjualan (Y1.1), Pertumbuhan penjuala (Y1.2) dan Porsi pasar (Y1.3). Dengan memperhatikan nilai original sample estimete yang positif dan signifikan tersebut maka dapat disimpulkan bahwa Orientasi Kewirausahaan akan meningkatkan Kinerja Pemasaran baik dari nilai penjualan, pertumbuhan dan porsi pasar.

Hal tersebut sejalan dengan penelitian Aristiyo \& Murwatiningsih (2017), Hasil penelitian menyatakan bahwa orientasi kewirausahaan, orientasi pasar terhadap kinerja pemasaran memiliki nilai signifikan, Pengaruh kemitraan terhadap kinerja pemasaran memiliki nilai tidak signifikan. Pengaruh orientasi kewirausahaan, orientasi pasar dan kemitraan terhadap keunggulan bersaing memiliki nilai signifikan, kemudian untuk pengaruh mediasi dihasilkan bahwa pengaruh total ketiga variaebel bebas lebih besar dari pengaruh langsungnya. Hasil dari penelitian ini membuktikan bahwa hanya kemitraan yang tidak berpengruh langsung terhadap kinerja pemasaran, sedangkan keunggulan bersaing memediasi pengaruh tidak langsung orientasi kewirausahaan, orientasi pasar, dan kemitraan terhadap kinerja pemasaran.

\section{Keunggulan Bersaing Berpengaruh Signifikan Terhadap Kinerja Pemasaran}

Demikian dapat disimpulkan bahwa Keunggulan bersaing direfleksikan oleh indikator Diferensiasi (Z1.2), dan Fokus (Z1.3) mempunyai pengaruh yang Signifikan terhadap Kinerja Pemasaran yang direfleksikan oleh Nilai Penjualan (Y.1), Pertumbuhan penjualan (Y1.2) dan Porsi pasar (Y1.3). Dengan memperhatikan nilai original sample estimete yang positif dan signifikan tersebut maka dapat disimpulkan bahwa Keunggulan bersaing akan meningkatkan Kinerja Pemasaran baik dari nilai penjualan, pertumbuhan dan porsi pasar. 
Hal tersebut sejalan dengan penelitian Yasa et al., (2020) Hasil penelitian menunjukkan bahwa strategi promosi berpengaruh positif dan signifikan keunggulan kompetitif dan strategi promosi sangat mampu meningkatkan daya saing keuntungan. Selanjutnya keunggulan bersaing berpengaruh positif dan signifikan terhadap pencapaian kinerja pemasaran. Artinya dengan keunggulan kompetitif yang lebih tinggi, terjadilah adalah kinerja pemasaran yang lebih besar dan keunggulan kompetitif mampu menengahi secara signifikan pengaruh strategi promosi terhadap kinerja pemasaran.

\section{Media Sosial Berpengaruh Signifikan Terhadap Kinerja Pemasaran}

Demikian dapat disimpulkan bahwa Media Sosial direfleksikan oleh indikator Partisipasi (X3.1), Keterbukaan (X3.2), Percakapan (X3.3), Komunitas (X3.4) dan Keterhubungan (X3.5) mempunyai pengaruh yang Signifikan terhadap kinerja Pemasaran yang direfleksikan oleh indikator Nilai Penjualan (Y1.1), Pertumbuhan penjualan (Y1.2) dan Porsi pasar (Y1.3). Dengan memperhatikan nilai original sample estimete yang positif dan signifikan tersebut maka dapat disimpulkan bahwa Media Sosial akan meningkatkan Kinerja Pemasaran baik dari nilai penjualan, pertumbuhan dan porsi pasar.

Hal tersebut sejalan dengan penelitian Tafesse \& Wien (2018), Hasilnya menunjukkan bahwa semua kecuali dimensi kehadiran aktif dari penerapan media sosial berhubungan positif dengan kinerja media sosial. Itu Hasil lebih lanjut menunjukkan bahwa kinerja media sosial adalah positif terkait dengan kinerja pemasaran. Studi ini berkontribusi pada sastra dengan menawarkan konseptualisasi novel dan empiris validasi konstruk implementasi media sosial.

\section{Orientasi Kewirausahaan Berpengaruh Terhadap Kinerja Pemasaran Di Mediasi Oleh Keunggulan Bersaing}

Berdasarkan hasil analisis data dan uji mediasi sobel test, Orientasi kewirausahaan (X1) tidak berpengaruh terhadap kinerja pemasaran (Y) melalui variabel keunggulan bersaing (Z) dengan nilai t-hitungnya $0,208<\mathrm{t}$ tabel 1,985 dengan p-value sebeser 0,835. Maka dapat disimpulkan bahwa keunggulan bersaing (Z) tidak mampu memediasi pengaruh Orientasi kewirausahaan (X1) terhadap kinerja pemasaran $(\mathrm{Y})$.

Penelitian ini tidak sejalan dengan Penelitian Zaini et al., (2014)Hasil penelitian menunjukkan bahwa terdapat pengaruh orientasi kewirausahaan terhadap kinerja pemasaran. Peran keunggulan bersaing sebagai mediator kinerja pemasaran sangat penting, namun tidak diikuti dengan orientasi pembelajaran, karena tidak terdapat pengaruh yang signifikan antara variabel ini terhadap kinerja pemasaran, Pada perbedaan ini, ada beberapa sebab di antarannya adalah adanya Variabel orientasi belajar pada penelitian (Zaini et al., 2014), sedangkan penelitian ini tidak menggunakan variabel orientasi belajar.

\section{Inovasi Produk Berpengaruh Terhadap Kinerja Pemasaran Di Mediasi Oleh Keunggulan Bersaing}

Berdasarkan hasil analisis data dan uji mediasi sobel test, Inovasi Produk (X2) berpengaruh terhadap kinerja pemasaran (Y) melalui variabel keunggulan bersaing (Z) dengan nilai t-hitungnya 2,560 $>\mathrm{t}$ tabel 1,985 dengan $\mathrm{p}$-value sebeser 0,010 . Maka dapat disimpulkan bahwa keunggulan bersaing $(\mathrm{Z})$ mampu memediasi pengaruh Inovasi Produk (X2) terhadap kinerja pemasaran (Y).

Penelitian ini sejalan dengan Penelitian Merakati et al., (2017) Hasil penelitian menunjukkan (1) orientansi pasar berpengaruh secara signifikan terhadap kinerja pemasaran baik langsung maupun tidak langsung melalui keunggulan bersaing sebesar $14,92 \%,(2)$ inovasi berpengaruh secara signifikan terhadap kinerja pemasaran baik langsung maupun tidak langsung melalui keunggulan bersaing sebesar 8,23\%,(3) 
orientansi kewirausahaan berpengaruh secara signifikan terhadap kinerja pemasaran baik langsung maupun tidak langsung melalui keunggulan bersaing sebesar 18,00 \% dan (4) keunggulan bersaing berpengaruh secara signifikan terhadap kinerja pemasaran sebesar $10,89 \%$, Pada perbedaan ini, ada beberapa sebab di antarannya adalah sampel penelitiannya UKM Sentral batik Trusmi adanya pada penelitian (Merakati et al., 2017) sedangkan penelitian ini menggunakan UKM di Kota jambi tidak spesifik seperti penelitian terdahulu yaitu UKM sentral Batik saja.

\section{Media Sosial Berpengaruh Terhadap Kinerja Pemasaran Di Mediasi Oleh Keunggulan Bersaing.}

Berdasarkan hasil analisis data dan uji mediasi sobel test, Media Sosial (X3) berpengaruh terhadap kinerja pemasaran $(\mathrm{Y})$ melalui variabel keunggulan bersaing $(\mathrm{Z})$ dengan nilai t-hitungnya 2,531 > t tabel 1,198 dengan p-value sebeser 0,011. Maka dapat disimpulkan bahwa keunggulan bersaing (Z) mampu memediasi pengaruh Media Sosial terhadap kinerja pemasaran (Y).

Hal tersebut sejalan dengan penelitian Purwantini \& Anisa (2018), Hasil pengujian dengan SEM-PLS Penggunaan media sosial bagi UMKM berdampak positif terhadap kinerja UMKM yaitu kinerja pelayanan pelanggan, penjualan, pemasaran dan operasi internal.Hal tersebut juga sejalan dengan penelitian Prihadi \& Susilawati (2018), Tujuan penelitian ini adalah mengetahui pengaruh kemampuan e-commerce dan promosi di media sosial terhadap kinerja pemasaran pegadang. Hasil penelitian ini menunjukkan bahwa: 1) kemampuan e-commerce berpengaruh tidak signifikan terhadap kinerja pemasaran pegadang, 2) promosi di media sosial berpengaruh signifikan terhadap kinerja pemasaran pegadang dan 3) kemampuan e-commerce dan promosi di media sosial secara simultan berpengaruh signifikan terhadap kinerja pemasaran pegadang.

\section{Simpulan dan Saran}

\section{Simpulan}

1. Orientasi Kewirausahaan yang direfleksikan oleh Keinovatifan, Pengambilan Resiko, Keaktifan, Keagresifan Bersaing dan Otonomi tidak mempunyai pengaruh yang Signifikan terhadap Keunggulan bersaing yang direfleksikan oleh Diferensiasi, dan Fokus.

2. Inovasi produk yang direfleksikan oleh Penemuan, Pengembangan, Duplikasi dan Sinetesis mempunyai pengaruh yang Signifikan terhadap Keunggulan bersaing yang direfleksikan oleh Diferensiasi, dan Fokus.

3. Media Sosial yang direfleksikan oleh Partisipasi, Keterbukaan, Percakapan, Komunitas dan Keterhubungan. mempunyai pengaruh yang Signifikan terhadap Keunggulan bersaing yang direfleksikan oleh Diferensiasi, dan Fokus.

4. Orientasi Kewirausahaan yang direfleksikan oleh Keinovatifan, Pengambilan Resiko, Keaktifan, Keagresifan Bersaing dan Otonomi mempunyai pengaruh yang Signifikan terhadap kinerja pemasaran yang direfleksikan oleh Nilai Penjualan, Pertumbuhan dan Porsi pasar.

5. Keunggulan bersaing yang direfleksikan oleh indikator Diferensiasi, dan Fokus mempunyai pengaruh yang Signifikan terhadap Kinerja Pemasaran yang direfleksikan oleh Nilai Penjualan, Pertumbuhan dan Porsi pasar.

6. Media Sosial yang direfleksikan oleh indikator Partisipasi, Keterbukaan, Percakapan, Komunitas dan Keterhubungan mempunyai pengaruh yang Signifikan terhadap kinerja Pemasaran yang direfleksikan oleh Nilai Penjualan, Pertumbuhan dan Porsi pasar. 
7. Orientasi kewirausahaan tidak berpengaruh terhadap kinerja pemasaran melalui variabel keunggulan bersaing maka keunggulan bersaing tidak mampu memediasi pengaruh Orientasi kewirausahaan terhadap kinerja pemasaran.

8. Inovasi Produk berpengaruh terhadap kinerja pemasaran melalui variabel keunggulan bersaing maka keunggulan bersaing mampu memediasi pengaruh Inovasi Produk terhadap kinerja pemasaran.

9. Media Sosial berpengaruh terhadap kinerja pemasaran melalui variabel keunggulan bersaing Maka keunggulan bersaing mampu memediasi pengaruh Media Sosial terhadap kinerja pemasaran

\section{Saran}

Merujuk dari hasil penelitian yang menyimpulkan bahwa sebaiknya Usaha Kecil dan Menegah di Kota Jambi harus meningkatkan inovasi produk seperti melakukan Penemuan, Pengembangan, Duplikasi, dan Sinetesis serta giat melakukan promosi atau memasarkan produk lewat media sosial karena akan mempermudah untuk melakukan partisipasi, keterbukaan, percakapan, komunitas, dan keterhubungan sehingga nanti diharapkan terciptannya keunggulan bersaing dan juga akan meningkatkan kinerja pemasaran yang lebih baik lagi dari sebelumnya.

Diharapkan pemerintah dapat lebih sering memberikan pelatihan-pelatihan untuk Usaha Kecil dan Menegah tentang, inovasi produk seperti cara melakukan Penemuan, Pengembangan, Duplikasi, dan Sinetesis dan juga seminar-seminar tentang pemanfaatan media sosial dikalangan Usaha Kecil dan Menegah untuk menigkatkan keunggulan bersaing dan kinerja pemasarannya.

Bagi akademisi diharapkan agar dapat memperluas objek penelitian tidak hanya pada satu UKM Kota Jambi saja, namun UKM di kabupaten lain atau Seprovinsi Jambi. Selain itu, penelitian selanjutnya diharapkan agar dapat meneliti yang lain seperti Variabel brand dan Influencer Terkait kinerja pemasaran.

\section{Daftar Pustaka}

Aristiyo, R., \& Murwatiningsih. (2017). Meningkatkan Kinerja Pemasaran Melalui Keunggulan Bersaing Dengan Orientasi Kewirausahaan, Orientasi Pasar, Dan Kemitraan. Management Analysis Journal, 6 (1), 44.

Augusty, F., \& Asatuan, A. (2004). Studi mengenai orientasi pengelolaan. Jurnal Sains Pemasaran Indonesia, Vol.3, No., 1-22.

Badan pusat statistik provinsi jambi.2018." Usaha Mikro, Kecil dan Menengah menurut Kab/Kota, 2012-2018”. https://jambi.bps.go.id/dynamictable/2018/10/03/697/jumlah-usaha-mikro kecil-dan-menengah-menurut-kab-kota-2012-2016.html

Barney, J. B., \& Clark, D. N. (2010). Gaining and Sustaining Competitive Advantage, Fourth Edition. Addison-Wesley, Massachusetts.

Barney, J. B., \& Hesterly, W. S. (2015). Strategic Management and Competitive Advantage Concepts and Cases Global Edition. Retrieved from www.pearsonglobaleditions.com

Brahmanthara, K. A., \& Yasa, N. N. K. (2017). Peran Keunggulan Bersaing Memediasi Inovasi Produk Terhadap Kinerja Pemasaran. Prosiding Seminar Nasional AIMI, Vol 8 No 1. https://doi.org/https://doi.org/10.36733/juima.v8i1.39

Dess, G. G. G. T. L. (2005). The Role of Entrepreneurial Orientation in Stimulating Effective Corporate Entrepreneurship Gregory. Academy of Management Executive, 2005, Vol. 19, No. 1, 33(6), 45-46. https://doi.org/10.1177/002248718203300610 
Dewi, N. M. P., \& Ekawati, N. W. (2017). Peran Keunggulan Bersaing Dalam Memediasi Pengaruh Orientasi Pasar Terhadap Kinerja Pemasaran. E-Jurnal Manajemen Unud, 6(9), 4947-4977. Retrieved from https://media.neliti.com/media/publications/249598-peran-keunggulan-bersaingdalam-memedias-e0588528.pdf

Dinas Koperasi dan UKM Kota Jambi.2019."Jumlah UMKM Perkecamatan

Ferdinand, A. (2000). Manajemen Pemasaran Sebuah Pendekatan Stratejik. Program Magister Manajemen Universitas Diponegoro, Semarang.

Ghozali, I. (2011). Aplikasi Analisis Multivariate Dengan Program SPSS. Semarang: Badan Penerbit Universitas Diponegoro.

Jayaningrum, E. (2018). pengaruh orientasi pasar, inovasi, orientasi kewirausahaan terhadap keunggulan bersaing dan kinerja pemasaran (studi pada kuliner kafe kota malang). 54(1), 149-158.

Karim, S., \& Hamdan, U. (2014). Analisis Modal Kerja Industri Kecil Usaha Pertukangan Kayu Dan Usaha Las Di Kota Palembang. Jurnal Manajemen Dan Bisnis Sriwijaya, Vol. 12 No, 1-227. https://doi.org/10.29259/jmbs.v12i3.3177

Keller, K. L. (2016). Marketing Management (15th ed.). Pearson Education.

Kennedy, G. (2015). Social Media: Master Social Media Marketing - Facebook, Twitter, YouTube \& Instagram.

Knight, G. (2016). Entrepreneurship and Marketing Strategy: The SME Under Globalization. 8(2), 12-32.

Lumpkin, G. T., \& Dess, G. G. (1996). clarifying the entrepreneurial orientation construct and linking it to performance. Academy of Management Review, Vol. 21, N, 135-172. Retrieved from http://www.jstor.org/stable/258632 .

Machfoedz, M., \& Machfoedz, M. (2004). kewirausahaan suatu pendekatan kontemporer. Unit penerbitan dan percetakan akademi manaejemen perusahaan YKPN

Merakati, I., Rusdarti, \& Wahyono. (2017). Pengaruh Orientasi Pasar,Inovasi, Orientansi Kewirausahaan melalui Keunggulan Bersaing Terhadap Kinerja Pemasaran. Journal of Economic Education, 6(2), 114-123. https://doi.org/10.15294/jeec.v6i2.19297

Mayfield, A. (2008). What is Social Media? Retrieved from icrossing.co.uk/ebooks \%3E

Nasrullah, R. (2015). Media Sosial: Perspektif Komunikasi, Budaya dan Sosioteknologi. Simbiosa Rekatama Media.

Octavia, A. (2017). Entrepreneurial Orientation Dan Management Skill Sebagai Anteseden Kinerja Bisnis Usaha Mikro, Kecil Dan Menengah (Umkm). Semlnar Naslonal Kewlrausahaan Dan Inovasl Blsnls VII.

Pranaka, A. S., Ghina, A., \& Putri, M. K. (2017). Pengaruh Media Sosial Instagram Terhadap Keunggulan Bersaing ( Studi Kasus Pada Usaha Menengah Guten Inc Bandung ) Influence Of Social Media Instagram To Competitive Advantage ( Case Study On Guten Inc Bandung ). Proceeding of Management, 4(3), 2272-2281. https://doi.org/ISSN : 2355-9357

Purwantini, A. H., \& Anisa, F. (2018). Analisis Penggunaan Media Sosial bagi UKM dan Dampaknya Terhadap Kinerja. The 7th University Research Colloquium, 304-314.

Rainey, D. (2005). Product Innovation Leading Change through Integrated Product Development. Published in the United States of America by Cambridge University Press, New York.

Rosli Mahmood, Mahmood, R., Aarakit, S. M., Alarape, A. A., Al-swidi, A. K., AlHosam, A., ... Me, N. (2013). Entrepreneurial orientation and business performance of women-owned small and medium enterprises in Malaysia: Competitive advantage 
as a mediator. International Journal of Business and Social Science, 4(1), 82-90. https://doi.org/10.1177/0266242612455034

Sarwono, H. A. (2015). Profil Bisnis Usaha Mikro, Kecil Dan Menengah (Umkm). In Bank Indonesia dan LPPI.

Setyawati, \& Abrilia, H. (2013). Pengaruh Orientasi Kewirausahaan Dan Orientasi Pasar Terhadap Kinerja Perusahaan Melalui Keunggulan Bersaing Dan Persepsi Ketidakpastian Lingkungan Sebagai Prediksi Variabel Moderasi (Survey Pada Umkm Perdagangan Di Kabupaten Kebumen. Jurnal Fokus Bisnis, Volume 12, 30. https://doi.org/10.32639/fokusbisnis.v12i2.3

Siqueira, A. C. O., \& Cosh, A. D. (2008). Effects of product innovation and organisational capabilities on competitive advantage: Evidence from UK small and medium manufacturing enterprises. International Journal of Innovation Management, 12(2), 113-137. https://doi.org/10.1142/S1363919608001972

Sugiyono. (2017). Metode Penelitian kuantitatif, kualitatif, dan R\&D. Alfabeta : Bandung.

Suryana, Y., \& Bayu, K. (2010). Kewirausahaan pendekatan karakteristik wirausahawan sukses. Kencana prenadamedia group.

Tafesse, W., \& Wien, A. (2018). Implementing social media marketing strategically: an empirical assessment. Journal of Marketing Management, 34(9-10), 732-749. https://doi.org/10.1080/0267257X.2018.1482365

Tajvidi, R., \& Karami, A. (2017). The effect of social media on firm performance. Computers in Human Behavior, 1-10. https://doi.org/10.1016/j.chb.2017.09.026

Tawas, H., \& Djodjobo, C. (2014). Pengaruh Orientasi Kewirausahaan, Inovasi Produk, Dan Keunggulan Bersaing Terhadap Kinerja Pemasaran Usaha Nasi Kuning Di Kota Manado. Jurnal Riset Ekonomi, Manajemen, Bisnis Dan Akuntansi, 2(3), 1214-1224. https://doi.org/10.35794/emba.v2i3.5800

Wardi, Y., Susanto, P., \& Abdullah, N. L. (2017). Orientasi kewirausahaan pada kinerja usaha kecil dan menegah (UKM) Sumatera Barat: Analisis peran moderasi dari intensitas persaingan, turbulensi pasar dan teknologi. Jurnal Manajemen Teknologi, Vol.16.No., 58. https://doi.org/10.12695/jmt.2017.16.1.4

Yacob, S., Octavia, A., Mayrina, \& Handri. (2018). Do Really Social Commerce Creating For Competitive Advantage On Small Medium Enterprises (Smes) Business Performance In Indonesia? Ijbr, Volume $18, \quad 80$. https://doi.org/dx.doi.org/10.18374/IJBR-18-2.6

Yasa, N. N. K., Ketut Giantari, I. G. A., Setini, M., \& Rahmayanti, P. L. D. (2020). The role of competitive advantage in mediating the effect of promotional strategy on marketing performance. Management Science Letters, 10(12), 2845-2848. https://doi.org/10.5267/j.msl.2020.4.024

Yaseen Zeebaree, M. R., \& Siron, R. B. (2017). International Review of Management and Marketing The Impact of Entrepreneurial Orientation on Competitive Advantage Moderated by Financing Support in SMEs. International Review of Management and Marketing, 7(1), 43-52. Retrieved from http:www.econjournals.com

Zaini, A., Hadiwidjojo, D., Rohman, F., \& Maskie, G. (2014). Effect Of Competitive Advantage As A Mediator Variable Of Entrepreneurship Orientation To Marketing Performance. IOSR Journal of Business and Management, 16(5), 05-10. https://doi.org/10.9790/487x-16510510

Zimmerer, T. W., Scarborough, N. M., \& Doug, W. (2008). Kewirausahaan dan manajemen usaha kecil. Salemba empat. 